\title{
EFEKTIVITAS DAN KONTRIBUSI PENERIMAAN PAJAK BUMI DAN BANGUNAN PERDESAAN DAN PERKOTAAN (PBB-P2) TERHADAP PENERIMAAN PENDAPATAN ASLI DAERAH (PAD) DI KOTA GORONTALO TAHUN 2016-2018
}

\author{
Cherry Agustine Chandra ${ }^{1}$, Harijanto Sabijono ${ }^{2}$, Treesje Runtu ${ }^{3}$ \\ 1, 2,3 Jurusan Akuntansi, Fakultas Ekonomi dan Bisnis, Universitas Sam Ratulangi, Jl. Kampus Bahu, Manado, \\ 95115, Indonesia
}

E-mail: cherry.a.chandra@gmail.com

\begin{abstract}
The Rural and Urban Land and Building Tax (PBB-P2) is a central tax which is handed over to the local government so that it becomes a local tax. PBB-P2 is expected to be able to contribute to the receptionof special regions. The purpose of this study is to calculate the acceptance and acceptance of $P B B-P 2$ revenue towards increasing $P A D$ revenue in Gorontalo City. The research method uses a qualitative type with Gorontalo City government as the object of research. Data collection techniques with interviews and documentation. The results showed that PBB-P2 revenues in Gorontalo City amounted to 88,86\% in 2016, 79,80\% in 2017, and 81,24\% in 2018, and receipt of PBB-P2 revenue towards PAD 2016 was $2,89 \%$, in 2017 it was $2,80 \%$, and 2018 it was $3,05 \%$.
\end{abstract}

Keywords: PBB-P2; local own-source revenue; effectiveness; contribution

\section{PENDAHULUAN}

Negara Kesatuan Republik Indonesia dibagi atas daerah-daerah provinsi yang terdiri atas daerah-daerah Kabupaten dan Kota. Pemerintah daerah memiliki kewenangan dalam menyelenggarakan kegiatan pelayanan kepada masyarakat, hal ini bertujuan untuk meningkatkan kualitas pelayanan publik. Sumber dana memegang peranan penting dalam penyelenggaraan pemerintahan dan pelaksanaan pembangunan di daerah. Salah satu sumber dana yang cukup berperan penting bagi kelangsungan pelaksanaan pembangunan dan penyelenggaran urusan pemerintahan adalah penerimaan dari Pendapatan Asli Daerah (PAD) yang berasal dari pajak daerah.

Undang-Undang Nomor 28 Tahun 2009 tentang Pajak Daerah dan Retribusi Daerah (UU PDRD) memberikan kewenangan kepada pemerintah daerah untuk melakukan perluasan objek pajak daerah sebagai sumber penghasilan tambahan. Perluasan objek pajak daerah yang diatur dalam Undang-Undang tersebut meliputi perluasan basis pajak daerah yang telah ada, penambahan objek pajak baru dan pendaerahan objek pajak pusat menjadi pajak daerah, salah satunya adalah Pajak Bumi dan Banguanan Perdesaan dan Perkotaan (PBB-P2).

Pelaksanaan Undang-Undang terkait pajak dan retribusi sebelumnya yaitu UndangUndang Nomor 18 Tahun 1997 dan Undang-Undang Nomor 34 Tahun 2000 belum dapat dilaksanakan secara optimal. Salah satunya adalah upaya penggalian PAD yang masih kurang yang disebabkan daerah belum mampu mengestimasi besar potensi pajak yang dimilikinya. Besarnya potensi pajak ini yang kemudian menjadi dasar penentuan target penerimaan per jenis pajak bagi daerah meskipun secara teoritis potensi dihitung dengan cara sederhana yakni mengalikan besarnya tarif dengan dasar pengenaan pajak namun pada kenyataanya tidaklah sesederhana itu.

Sejak bulan Januari 2014, Pajak Bumi dan Bangunan Sektor Pedesaan dan Perkotaan (PBB-P2) secara resmi dikelola oleh pemerintah daerah. Adanya pengalihan PBB-P2 kepada daerah diharapkan dapat meningkatkan $\mathrm{PAD}$, memperbaiki struktur APBD, meningkatkan 
pelayanan kepada masyarakat, serta memperbaiki aspek transparansi dan akuntabilitas pengelolaan di daerah (Napitupulu dan Budiarso, 2015). Daerah masih mengalami beberapa masalah dalam pengelolaan PBB-P2, antara lain masih adanya daerah yang belum menerbitkan peraturan kepala daerah mengenai pelaksanaan pengelolaan PBB-P2, lemahnya sistem pengelolaan basis data objek, subjek dan wajib pajak, dan lemahnya sistem administrasi dan pelayanan kepada masyarakat wajib pajak. Hal tersebut semuanya terkait dengan terbatasnya kesiapan sarana/prasarana, organisasi, dan sumber daya masyarakat di daerah yang bertugas melakukan pemungutan PBB-P2.

Pajak berperan signifikan dalam perekonomian Kota Gorontalo dan membantu meningkatkan PAD Kota Gorontalo dengan berbagai sektor, diantaranya Pajak Hotel, Pajak Restoran, Pajak Hiburan, Pajak Reklame, Pajak Penerangan Jalan, Pajak Mineral Bukan Logam dan Batuan, Pajak Parkir, Pajak Air Tanah, dan Pajak Sarang Burung Walet, Pajak Bumi dan Bangunan Perdesaan dan Perkotaan, dan Bea perolehan Hak atas Tanah dan Bangunan. Peraturan Daerah Kota Gorontalo Nomor 9 Tahun 2011 tentang Pajak Bumi dan Bangunan Perdesaan dan Perkotaan, menetapkan bahwa Pemerintah Kota Gorontalo melakukan pengelolaan PBB-P2 sejak tanggal 1 Januari 2012, selain mengelola besarnya PBB-P2, pemerintah Kota Gorontalo juga perlu mengetahui tingkat efektivitas dan kontribusi PBB-P2 terhadap Pendapatan Asli Daerah (PAD) di Kota Gorontalo.

\section{TINJAUAN PUSTAKA}

Akuntansi perpajakan. Supriyanto (2015:2-3) menjelaskan bahwa akuntansi pajak adalah suatu proses pencatatan, penggolongan dan pengikhtisaran suatu transaksi keuangan kaitannya dengan kewajiban perpajakan dan diakhiri dengan pembuatan laporan keuangan fiskal sesuai dengan ketekunan dan peraturan perpajakan yang terkait sebagai dasar pembuatan surat pemberitahuan tahunan (SPT).

Pajak daerah. Berdasarkan Undang-Undang Republik Indonesia Nomor 28 Tahun 2009, yang dimaksud dengan pajak daerah adalah kontribusi wajib kepada daerah yang terutang oleh orang pribadi atau badan yang bersifat memaksa berdasarkan Undang-Undang, dengan tidak mendapatkan imbalan secara langsung dan digunakan untuk keperluan daerah bagi sebesar-besarnya kemakmuran rakyat.

Pajak Bumi dan Bangunan Perdesaan dan Perkotaan. Pajak Bumi dan Bangunan Perdesaan dan Perkotaan (PBB-P2) adalah pajak negara yang dikenakan terhadap bumi (meliputi, tanah dan perairan pedalaman termasuk rawa-rawa, tambak, perairan serta laut wilayah Republik Indonesia. Bangunan adalah konstruksi teknik yang ditanam atau dilekatkan secara tetap pada tanah dan/atau perairan. Berdasarkan Undang-Undang Nomor 12 tahun 1985 tentang pajak bumi dan bangunan sebagaimana telah diubah dengan UndangUndang Nomor 12 tahun 1994 tanggal 9 November 1994 (Mardiasmo, 2018:363).

Dasar Hukum Pemungutan Pajak Bumi dan Bangunan Perdesaan dan Perkotaan. Dasar hukum pemungutan PBB-P2 pada suatu Kabupaten/Kota adalah: (1) Undang-UndangNomor 28 Tahun 2009 tentang Pajak Daerah dan Retribusi Daerah; (2) Peraturan Daerah Kabupaten/Kota yang mengatur tentang PBB-P2; dan (3) Keputusan Bupati/Walikota yang mengatur tentang PBB-P2 sebagai aturan pelaksanaan peraturan daerah tentang PBB-P2 pada kabupaten/kota yang dimaksud.

Efektivitas. Efektivitas adalah ukuran berhasil tidaknya pencapaian tujuan suatu organisasi dalam mencapai tujuannya. Apabila suatu organisasi mencapai tujuan maka organisasi tersebut telah berjalan dengan efektif. Indikator efektivitas menggambarkan jangkauan akibat dan dampak (outcome) dari keluaran (output) program dalam mencapai tujuan program. Semakin besar kontribusi output yang dihasilkan terhadap pencapaian tujuan atau sasaran yang ditentukan, maka semakin efektif proses kerja suatu unit organisasi 
(Mardiasmo, 2017:134). Adapun cara untuk mengukur efektivitas penerimaan pajak bumi dan bangunan perdesaan dan perkotaan adalah sebagai berikut:

$$
\text { Efektivitas }=\frac{\text { Realisasi PBB-P2 }}{\text { Target PBB-P2 }} \times 100 \%
$$

Tingkat efektivitas pengelolaan Pajak Bumi dan Bangunan Perdesaan dan Perkotaan terhadap peningkatan penerimaan pendapatan asli daerah, dengan menggunakan kriteria dan indikator:

Tabel 1. Klasifikasi pengukuran efektivitas

\begin{tabular}{cc}
\hline Persentase & Kriteria \\
\hline$>100 \%$ & Sangat Efektif \\
$90-100 \%$ & Efektif \\
$80-90 \%$ & Cukup Efektif \\
$60-80 \%$ & Kurang Efektif \\
$<60 \%$ & Tidak Efektif
\end{tabular}

Sumber: Depdagri, Kepmendagri No. 690.900.327 Tahun 1996

Kontribusi. Kontribusi adalah suatu tindakan untuk ikut serta bertindak aktif dengan mengoptimalkan kemampuan sesuai bidang dan kapasitas masing-masing yang digunakan untuk mengetahui sejauh mana pajak daerah memberikan sumbangan dalam penerimaan PAD. Penghitungan kontribusi dilakukan dengan membandingkan penerimaan pajak daerah (khususnya Pajak Bumi dan Bangunan Perdesaan Perkotan) periode tertentu dengan penerimaan PAD periode tertentu (Mahmudi, 2010:12). Rasio kontribusi digunakan untuk mengetahui seberapa besar kontribusi dari Pajak Bumi dan Bangunan terhadap Pendapatan Asli Daerah di Kota Gorontalo. Adapun cara untuk mengukur kontribusi penerimaan Pajak Bumi dan Bangunan Perdesaan Dan Perkotaan adalah sebagai berikut:

$$
\text { Kontribusi }=\frac{\text { Jumlah Penerimaan PBB-P2 }}{\text { Jumlah Penerimaan PAD }} \times 100 \%
$$

Tingkat kontribusi Pajak Bumi Dan Bangunan Perdesaan dan Perkotaan terhadap peningkatan penerimaan pendapatan asli daerah, menggunakan kriteria dan indikator sebagai berikut.:

Tabel 2. Klasifikasi pengukuran kontribusi

\begin{tabular}{cc}
\hline Persentase & Kriteria \\
$0,00 \%-10 \%$ & Sangat Kurang \\
$10,10-20 \%$ & Kurang \\
$20,10-30 \%$ & Sedang \\
$30,10-40 \%$ & Cukup Baik \\
$40,10-50 \%$ & Baik \\
Diatas $50 \%$ & Sangat Baik \\
\hline
\end{tabular}

Sumber: Depdagri, Kepmendagri No. 690.900.327 Tahun 1996

Pendapatan Asli Daerah. Menurut Undang-Undang Nomor 33 Tahun 2004 tentang Perimbangan Keuangan antara Pusat dan Daerah pasal 1 angka 18 menyatakan bahwa Pendapatan Asli Daerah yang disebut PAD adalah pendapatan yang diperoleh daerah yang dipungut berdasarkan peraturan daerah sesuai dengan peraturan perundang-undangan, bahwa 
Pendapatan Asli Daerah bersumber dari hasil pajak daerah, hasil retribusi, hasil pengelolaan kekayaan daerah yang dipisahkan dan lain-lain Pendapatan Asli Daerah yang sah.

Penelitian terdahulu. Wardani dan Fadhlia (2017) menunjukkan bahwa tingkat efektivitas penerimaan PBB-P2 terhadap PAD di Kabupaten Aceh Besar rata-rata sebesar $100,10 \%$ (sangat efektif), sedangkan kontribusi rata-rata adalah 2,08\% (sangat kurang). Chichi et al. (2017) menunjukkan bahwa tingkat efektivitas PBB-P2 di Kabupaten Minahasa Utara adalah sebesar 103,26\% (sangat efektif), Kota Manado sebesar 95,52\% (efektif), Kabupaten Minahasa sebesar 69,78\% (kurang efektif), sedangkan kontribusi pada Kabupaten Minahasa adalah sebesar 5,29\% (sangat kurang), Kabupaten Minahasa Utara sebesar 17,27\% (kurang), dan pada Kota Manado adalah sebesar 9,46\% (sangat kurang). Lintong et al. (2018) menunjukkan bahwa efektivitas PBB-P2 di Kota Manado adalah sebesar 95,52\% (efektif) lebih tinggi dari Kabupaten Minahasa Selatan yang hanya sebesar 88,12\% (cukup efektif), sedangkan kontribusi dalam pendapatan PBB-P2 pada Pendapatan Asli Daerah Kabupaten Minahasa Selatan adalah sebesar 4,55\% (sangat kurang), dan Kota Manado sebesar 9,46\% (sangat kurang). Anisa et al. (2019) menunjukkan bahwa tingkat efektivitas PBB-P2 terhadap PAD Kabupaten Magetan pada tahun 2014-2018 adalah sebesar 108, 61\% (sangat efektif) dan memiliki kontribusi sebesar 10,08\% (kurang). Wibisono dan Mulyani (2019) menyatakan bahwa efektivitas PBB-P2 terhadap PAD Kabupaten Tasikmalaya adalah 111,8\% (efektif), dan kontribusi sebesar 35,43\% (cukup baik). Tambingon et al. (2019) menunjukkan bahwa efektivitas penerimaan Pajak Bumi dan Bangunan Perdesaan dan Perkotaan di Kabupaten Minahasa Selatan tahun 2016-2017 secara rata-rata adalah sebesar 79,54\% dengan kategori kurang efektif.

\section{METODE PENELITIAN}

Jenis data yang digunakan yaitu data kualitatif dan data kuantitatif. Data kualitatif berupa hasil wawancara dan gambaran umum Badan Keuangan Kota Gorontalo dan data kuantitatif berupa laporan target dan realisasi penerimaan PAD tahun 2016-2018, laporan penerimaan PBB-P2 dan jumlah pajak tahun 2016-2018 Kota Gorontalo. Sumber yang digunakan peneliti adalah data primer yang diperoleh langsung dari Badan Keuangan Kota Gorontalo. Data berupa laporan target dan realisasi penerimaan PAD tahun 2016-2018, laporan penerimaan PBB-P2 dan jumlah pajak tahun 2016-2018. Penelitian ini menggunakan metode analisis deskriptif. Penelitian deskriptif ini menggambarkan keadaan penerimaan Pajak Bumi dan Bangunan Perdesaan dan Perkotaan berdasarkan data yang diperoleh dan dibutuhkan yang ada pada Badan Keuangan Kota Gorontalo.

\section{HASIL PENELITIAN DAN PEMBAHASAN}

4.1. Target dan realisasi PBB-P2, pajak daerah dan Pendapatan Asli Daerah Kota Gorontalo

Tabel 3. Target dan realisasi PBB-P2 Kota Gorontalo tahun 2016-2018

\begin{tabular}{ccc}
\hline Tahun & Target (Rp) & Realisasi (Rp) \\
\hline 2016 & 5.600 .000 .000 & 4.976 .349 .665 \\
2017 & 7.000 .000 .000 & 5.586 .128 .760 \\
2018 & 7.250 .000 .000 & 5.889 .669 .120 \\
\hline
\end{tabular}

Sumber: Badan Keuangan Kota Gorontalo, 2019

Tabel 3 menunjukan bahwa target Pajak Bumi dan Bangunan Perdesaan dan Perkotaan Kota Gorontalo mengalami kenaikan dari tahun ke tahunnya. Target Pajak Bumi dan Bangunan Perdesaan dan Perkotaan tahun 2016 sebesar Rp. 5.600.000.000 dan realisasinya sebesar Rp. 4.976.349.665. Pada tahun 2017 sebesar Rp. 7.000.000.000 dan 
realisasinya sebesar Rp. 5.586.128.760. Pada tahun 2018 target Rp. 7.250.000.000 dengan realisasi Rp. 5.889.669.120.

Tabel 4. Target dan realisasi pajak daerah Kota Gorontalo tahun 2016-2018

\begin{tabular}{ccc}
\hline Tahun & Target $(\mathbf{R p )}$ & Realisasi $($ Rp) \\
\hline 2016 & 46.850 .000 .000 & 45.676 .661 .215 \\
2017 & 60.721 .671 .497 & 60.657 .343 .915 \\
2018 & 70.000 .000 .000 & 61.774 .588 .856 \\
\hline
\end{tabular}

Sumber: Badan Keuangan Kota Gorontalo, 2019

Berdasarkan Tabel 4 dapat dilihat bahwa target Pajak Daerah tahun 2016 adalah sebesar Rp. 46.850.000.000 dengan realisasi sebesar Rp. 45.676.661.215, untuk tahun 2017 target sebesar Rp. 60.721.671.497 dengan realisasi sebesar Rp. 60.657.343.915 dan tahun 2018 target sebesar Rp. 70.000.000.000 dengan realisasi sebesar Rp. 61.774.588.856.

Tabel 5. Target dan realisasi Pendapatan Asli Daerah Kota Gorontalo tahun 2016-2018

\begin{tabular}{ccc}
\hline Tahun & $\begin{array}{c}\text { Target } \\
(\mathbf{R p})\end{array}$ & $\begin{array}{c}\text { Realisasi } \\
(\mathbf{R p})\end{array}$ \\
\hline 2016 & 191.207 .291 .450 & $172.315 .775 .595,42$ \\
2017 & 237.521 .987 .575 & 199.658 .715 .483 \\
2018 & 220.343 .322 .064 & 193.094 .494 .790 \\
\hline
\end{tabular}

Sumber: Badan Keuangan Kota Gorontalo, 2019

Tabel 5 menunjukkan bahwa angka realisasi Pendapatan Asli Daerah di Kota Gorontalo yang berfluktuasi dari tahun 2016 sampai dengan tahun 2018. Pada tahun 2016 target penerimaan PAD Kota Gorontalo sebesar Rp. 191.207.291.450 dan realisasi Rp. 172.315.775.595,42. Tahun 2017 target sebesar Rp. 237.521.987.575 dan realisasi sebesar Rp. 199.658.715.483. Pada tahun 2018 target adalah sebesar Rp 220.343.322.064 dan realisasi sebesar Rp. 193.094.494.790.

\section{Efektivitas Penerimaan PBB-P2 Kota Gorontalo}

1. Tahun 2016

Berdasarkan target penerimaan Pajak Bumi dan Bangunan Perdesaan dan Perkotaan Rp. 5.600.000.000 dengan realisasi sebesar Rp. 4.976.349.665, maka efektivitas Pajak Bumi dan Bangunan Perdesaan dan Perkotaan tahun 2016:

Efektivitas $=\frac{4.976 .349 .665}{5.600 .000 .000} \times 100 \%=88,86 \%$

Jadi tingkat efektivitas penerimaan Pajak Bumi dan Bangunan Perdesaan dan Perkotaan tahun 2016 sebesar $88,86 \%$.

2. Tahun 2017

Berdasarkan target penerimaan Pajak Bumi dan Bangunan Perdesaan dan Perkotaan Rp. 7.000.000.000 dengan realisasi sebesar Rp. 5.586.128.760, maka efektivitas Pajak Bumi dan Bangunan Perdesaan dan Perkotaan tahun 2017:

Efektivitas $=\frac{5.586 .128 .760}{7.000 .000 .000} \times 100 \%=79,80 \%$

Jadi tingkat efektivitas penerimaan Pajak Bumi dan Bangunan Perdesaan dan Perkotaan tahun 2017 sebesar 79,80\%. 
3. Tahun 2018

Berdasarkan target penerimaan Pajak Bumi dan Bangunan Perdesaan dan Perkotaan sebesar Rp. 7.250.000.000 dengan realisasi sebesar Rp. 5.889.669.120, maka efektivitas Pajak Bumi dan Bangunan Perdesaan dan Perkotaan tahun 2018:

Efektivitas $=\frac{5.889 .669 .120}{7.250 .000 .000} \times 100 \%=81,24 \%$

Jadi tingkat efektivitas penerimaan Pajak Bumi dan Bangunan Perdesaan dan Perkotaan tahun 2018 sebesar $81,24 \%$.

Tabel 6. Efektivitas PBB-P2 Kota Gorontalo tahun 2016-2018

\begin{tabular}{ccccc}
\hline Tahun & $\begin{array}{c}\text { Target } \\
(\mathbf{R p})\end{array}$ & $\begin{array}{c}\text { Realisasi } \\
(\mathbf{R p})\end{array}$ & $\begin{array}{c}\text { Persentase } \\
(\mathbf{\%})\end{array}$ & Kriteria \\
\hline 2016 & 5.600 .000 .000 & 4.976 .349 .665 & 88,86 & Cukup Efektif \\
2017 & 7.000 .000 .000 & 5.586 .128 .760 & 79,80 & Kurang Efektif \\
2018 & 7.250 .000 .000 & 5.889 .669 .120 & 81,24 & Cukup efektif \\
\hline \multicolumn{7}{c}{ Rata-Rata } & $\mathbf{8 3 , 3}$ & Cukup efektif \\
\hline
\end{tabular}

Sumber: Data olahan, 2020

Perhitungan efektivitas dilakukan dengan cara membandingkan realisasi pemungutan Pajak Bumi dan Bangunan Perdesaan dan Perkotaan dengan target pemungutan Pajak Bumi dan Bangunan Perdesaan dan Perkotaan. Berdasarkan hasil perhitungan efektivitas pajak bumi dan bangunan perdesaan dan perkotaan tahun 2016 sampai dengan tahun 2018 belum mencapai target yang telah ditetapkan dengan kriteria efektivitas cukup efektif dari $80 \%$. Pada tahun 2016 persentase 88,86\% dengan kategori cukup efektif, pada tahun 2017 persentase $79,80 \%$ lebih rendah dibandingkan tahun sebelumnya termasuk didalam kategorikurang efektif, pada tahun 2018 sebesar 81,24\%, dan untuk rata-rata efektivitasnya sebesar 83,3\% dengan kategori cukup efektif. Jadi kesimpulan yang dapat diambil bahwa pemungutan Pajak Bumi dan Bangunan Perdesaan dan Perkotaan dari tahun 2016 sampai dengan tahun 2018 dinilai cukup efektif.

\section{Kontribusi PBB-P2 terhadap PAD Kota Gorontalo}

1. Tahun 2016

Kontribusi $=\frac{4 \cdot 976.349 .665}{172.315 .775 .595,42} \times 100 \%=2,89 \%$

Hasil perhitungan menunjukkan bahwa penerimaan Kontribusi Pajak Bumi dan Bangunan Perdesaan dan Perkotaan Kota Gorontalo pada tahun 2016 sebesar 2,89\%.

2. Tahun 2017

Kontribusi $=\frac{5.586 .128 .760}{199.658 .715 .483} \times 100 \%=2,80 \%$

Hasil perhitungan menunjukkan bahwa penerimaan Kontribusi Pajak Bumi dan Bangunan Perdesaan dan Perkotaan Kota Gorontalo pada tahun 2017 sebesar 2,80\%.

3. Tahun 2018

Kontribusi $=\frac{5.889 .669 .120}{193.094 .494 .790} \quad \mathrm{x} 100 \%=3,05 \%$ 
Hasil perhitungan menunjukkan bahwa penerimaan Kontribusi Pajak Bumi dan Bangunan Perdesaan dan Perkotaan Kota Gorontalo pada tahun 2018 sebesar 3,05\%.

Tabel 7. Kontribusi Pajak Bumi dan Bangunan Perdesaan dan Perkotaan (PBB-P2) terhadap Pendapatan Asli Daerah (PAD) Kota Gorontalo tahun 2016-2018

\begin{tabular}{ccccc}
\hline Tahun & $\begin{array}{c}\text { Realisasi } \\
\text { PBB-P2 } \\
(\mathbf{R p})\end{array}$ & $\begin{array}{c}\text { Realisasi PAD } \\
(\mathbf{R p})\end{array}$ & $\begin{array}{c}\text { Persentase } \\
(\mathbf{\%})\end{array}$ & Kriteria \\
\hline 2016 & 4.976 .349 .665 & $172.315 .775 .595,42$ & 2,89 & Sangat Kurang \\
2017 & 5.586 .128 .760 & 199.658 .715 .483 & 2,80 & Sangat Kurang \\
2018 & 5.889 .669 .120 & 193.094 .494 .790 & 3,05 & Sangat Kurang \\
\hline \multicolumn{7}{c}{ Rata-Rata } & & $\mathbf{2 , 9 1}$ & Sangat Kurang \\
\hline
\end{tabular}

Sumber: Data olah, 2020

Perhitungan kontribusi dilakukan dengan cara membandingkan realisasi pemungutan Pajak Bumi dan Bangunan Perdesaan dan Perkotaan dengan realisasi Pendapatan Asli Daerah. Berdasarkan hasil perhitungan kontribusi Pajak Bumi dan Bangunan Perdesaan dan Perkotaan tahun 2016 sampai dengan tahun 2018 menunjukan bahwa Pajak Bumi dan Bangunan Perdesaan dan Perkotaan memberikan kontribusi masih sangat kurang bagi Pendapatan Asli Daerah dengan kriteria dibawah 10\%. Hasil penghitungan menunjukkan bahwa persentase kontribusi tahun 2016 adalah sebesar 2,89\% dengan kriteria sangat kurang, tahun 2017 adalah sebesar 2,80\% dengan kriteria sangat kurang, dan tahun 2018 adalah sebesar 3,05\% dengan kriteria sangat kurang. Rata-rata kontribusi tahun 2016 sampai 2018 adalah sebesar 2,91\% dengan kriteria sangat kurang. Jadi kontribusi dari sektor Pajak Bumi dan Bangunan Perdesaan dan Perkotaan terhadap Pendapatan Asli Daerah tahun 2016 sampai dengan tahun 2018 masih sangat kurang.

\subsection{Pembahasan}

Hasil penelitian menunjukkan bahwa tingkat efektivitas pajak bumi dan bangunan perdesaan dan perkotaan dari tahun 2016 sampai dengan tahun 2018 menunjukan nilai efektivitas yang cukup efektif yaitu pada tahun 2016 sebesar 88,86\%, tahun 2017 sebesar 79,80\%, dan tahun 2018 sebesar 81,24\%. Ini menunjukkan bahwa Badan Keuangan Kota Gorontalo cukup efektif dalam mengelola Pajak Bumi dan Bangunan Perdesaan dan Perkotaan di Kota Gorontalo.

Realisasi penerimaan Pajak Bumi dan Bangunan yang ada pada tahun 2016 sampai dengan tahun 2018 berfluktuasi, pada tahun 2017 mengalami penurunan, ini berarti ada faktor-faktor yang menyebabkan menurunnya realisasi Pajak Bumi dan Bangunan Perdesaan dan Perkotaan meskipun target yang ditetapkan pemerintah meningkat setiap tahunnya. Berdasarkan hasil wawancara, realisasi penerimaan PBB-P2 terhadap target yang telah ditetapkan masih belum terealisasi sesuai target yang ditetapkan lebih banyak disebabkan oleh kesadaran membayar pajak oleh wajib pajak yang rendah. Adapun faktor yang menghambat realisasi penerimaan PBB-P2 diantaranya wajib pajak yang alpa dalam pelunasan $\mathrm{PBB}-\mathrm{P} 2$, tingkat pengetahuan wajib pajak yang kurang tentang $\mathrm{PBB}-\mathrm{P} 2$, tingkat pendapatan wajib pajak yang diperoleh setiap bulannya yang rendah, dan wajib pajak yang berdomisili di luar daerah. Hal ini patut mendapat perhatian yang lebih lanjut dan menjadi bahan untuk evaluasi pemerintah dalam hal ini Badan Keuangan Kota Gorontalo, agar target yang ditetapkan setiap tahunnya bisa tercapai. Pemerintah dalam hal ini pihak Badan Keuangan Kota Gorontalo juga berupaya untuk memudahkan proses pemungutan pajak dengan bekerja sama dengan pihak perbankan seperti Bank Sulutgo, Bank Negara Indonesia 46, Kantor Pos, dan aplikasi pembayaran sistem online melalui android (seperti, LinkAja!, Dana, dan Ovo), meningkatkan kualitas pelayanan petugas pajak, serta melakukan 
penyuluhan kepada masyarakat untuk meningkatkan pemahaman dan pengetahuan wajib pajak akan pajak salah satunya PBB-P2.

Kontribusi Pajak Bumi dan Bangunan Perdesaan dan Perkotaan terhadap Kota Gorontalo untuk tahun 2016 adalah 2,89\%, tahun 2017 sebesar 2,80\%, tahun 2018 sebesar $3,05 \%$. Angka tersebut menurut klasifikasi kriteria kontribusi yang telah ditetapkan oleh Kemendagri menunjukan posisi yang sangat kurang. Dapat diketahui bahwa Pajak Bumi dan Bangunan Perdesaan dan Perkotaan di Kota Gorontalo yang kecil memberikan kontribusi ke Pendapatan Asli Daerah kurang, dibandingkan dengan penerimaan melalui sektor pajak yang lain dan juga dari pendapatan daerah lainnya. Berdasarkan hasil wawancara hal inilah yang menyebabkan mengapa kurangnya kontribusi dari Pajak Bumi dan Bangunan Perdesaan dan Perkotaan. Pemerintah Daerah harus lebih serius dalam memperhatikan, memanfaatkan dan mengoptimalkan sumber-sumber penerimaan yang berkaitan dengan objek Pajak Bumi dan Bangunan Perdesaan dan Perkotaan, sehingga kontribusi PBB-P2 sebagai pajak daerah kurang efektif. Dikarenakan Pajak Bumi dan Bangunan Perdesaan dan Perkotaan ini merupakan salah satu bagian dari sumber pendapatan daerah, sehingga dari seluruh sektor pajak yang ada di Kota Gorontalo ada yang lebih unggul dalam memberikan kontribusinya bagi Pendapatan Asli Daerah.

\section{KESIMPULAN DAN SARAN}

\subsection{Kesimpulan.}

Berdasarkan hasil penelitian dan pembahasan yang telah dilakukan mengenai efektifitas dan kontribusi Pajak Bumi dan Bangunan Perdesaan dan Perkotaan (PBB-P2) terhadap penerimaan Pendapatan Asli Daerah di Kota Gorontalo dapat disimpulkan sebagai berikut:

1. Efektivitas Pajak Bumi dan Bangunan Perdesaan dan Perkotaan di Kota Gorontalo dari tahun 2016 sampai dengan tahun 2018 dari hasil penelitian berada dikisaran 80\%. Dimana pada tahun 2016 tingkat persentase sebesar 88,86\% (cukup efektif), tahun 2017 dengan persentase 79,80\% (kurang efektif), tahun 2018 dengan persentase 81,24\% (cukup efektif), dengan rata-rata 83,30\% (cukup efektif). Karena target penerimaan PBB-P2 yang naik setiap tahunnya sedangkan realisasi penerimaan PBB-P2 yang mencapai target. pemerintah harus lebih memperhatikan lagi sumber-sumber penerimaan pajak yang berasal dari PBB-P2 agar supaya dapat mencapai target realisasi penerimaan PBB-P2 yang telah ditetapkan dan memberikan sanksi kepada wajib pajak yang tidak patuh membayar pajak, meningkatkan kualitas pelayanan petugas pajak, melakukan penyuluhan kepada masyarakat untuk meningkatkan pemahaman dan pengetahuan wajib pajak.

2. Kontribusi Pajak Bumi dan Bangunan Perdesaan dan Perkotaan terhadap Pendapatan Asli Daerah sebesar 2,91\%. Dimana berdasarkan kriteria dan indikator penilaian menjelaskan bahwa kontribusi tersebut sangat kurang, hal ini disebabkan rata-ratanya berada dibawah 10\%, walaupun persentase rata-rata kontribusi Pajak Bumi dan Bangunan Perdesaan dan Perkotaan kecil tetapi dapat mempengaruhi jumlah PAD Kota Gorontalo.

\subsection{Saran}

1. Pemerintah diharapkan lebih memperhatikan sumber-sumber penerimaan yang berkaitan dengan Pajak Bumi dan Bangunan Perdesaan dan Perkotaan sehingga diharapkan bisa berkontribusi sebagai pajak daerah dan memenuhi target yang telah ditetapkan. Dengan melakukan berbagai macam penyuluhan kepada masyarakat tentang PBB-P2 untuk menunjang kesejahteraan masyarakat melalui pelaksanaan pembangunan.

2. Pemerintah sebaiknya melakukan pendataan ulang wajib PBB-P2 agar potensi-potensi baru atas pajak tersebut dapat terdata dengan baik.

3. Pemerintahan dalam hal ini Badan Keuangan Kota Gorontalo harus meningkatkan pelayanan petugas pada saat menerima PBB-P2 dari wajib pajak dan memberi 
kemudahan-kemudahan dalam pemungutan PBB-P2 sehingga sikap penghindaran membayar pajak oleh wajib pajak dapat teratasi.

\section{DAFTAR PUSTAKA}

Anisa, N., Nuraina, E., \& Wihartanti, L. V. (2019). Analisis efektivitas dan kontribusi PBBP2 untuk meningkatkan Pendapatan Asli Daerah Kabupaten Magetan. Promosi: Jurnal $\begin{array}{llll}\text { Program Studi Pendidikan } & \text { Ekonomi, }\end{array}$ http://ojs.fkip.ummetro.ac.id/index.php/ekonomi/article/view/2513

Chichi, J., Nangoi, G. B.,\& Pangerapan, S. (2017). Analisis efektivitas dan kontribusi Pajak Bumi Dan Bangunan Perdesaan dan Perkotaan (PBB-P2) sebagai sumber Pendapatan Asli Daerah Kabupaten Minahasa, Kabupaten Minahasa Utara, dan Kota Manado. Going Concern: Jurnal Riset Akuntansi, 12(2), 742-753. https://doi.org/10.32400/gc.12.2.18052.2017

Lintong, F., Sabijono, H., \& Kalalo, M. Y. B. (2018). Analisis efektivitas dan kontribusi Pajak Bumi dan Bangunan Perdesaan dan Perkotaan (PBB-P2) terhadap peningkatan penerimaan Pendapatan Asli Daerah di Kabupaten Minahasa Selatan dan Kota Manado. Going Concern: Jurnal Riset Akuntansi, 13(4), 200-209. https://doi.org/10.32400/gc.13.04.20989.2018

Keputusan Menteri Dalam Negeri Nomor 690.900.327 Tahun 1996 tentang Pedoman Penilaian dan Kinerja Keuangan

Mahmudi. (2010). Manajemen Kinerja Sektor Publik. Jakarta. STIM YKPN.

Mardiasmo. (2017). Perpajakan Edisi Terbaru. Yogyakarta. Andi.

Mardiasmo. (2018). Perpajakan Edisi Terbaru. Yogyakarta. Andi.

Napitupulu, L. S., \& Budiarso, N. S. (2015). Pajak Bumi dan Bangunan Perdesaan Dan Perkotaan (PBB-P2) sebagai pajak daerah dan implikasinya terhadap pencatatan akuntansi pada Pemerintah Kota Manado. Jurnal Emba: Jurnal Riset Ekonomi, Manajemen, Bisnis dan Akuntansi, 3(1), 463-472. https://ejournal.unsrat.ac.id/index.php/emba/article/view/7157

Supriyanto. (2015). Akuntansi Perpajakan. Yogyakarta: Graha Ilmu.

Tambingon, V. V., Manossoh, H., \& Budiarso, N. S. (2019). Analisis strategi penerimaan Pajak Bumi dan Bangunan Perdesaan dan Perkotaan (PBB P2) serta efektivitas penerimaannya di pemerintah Kabupaten Minahasa Selatan tahun 2016-2017. Going Concern: Jurnal Riset Akuntansi, $14(1), \quad 80-88$. https://doi.org/10.32400/gc.14.1.22290.2019

Undang-Undang Republik Indonesia Nomor 28 Tahun 2009 tentang Pajak Daerah dan Retribusi Daerah.

Undang-Undang Republik Indonesia Nomor 33 Tahun 2004 tentang Perimbangan Keuangan antara Pemerintah Pusat dan Pemerintahan Daerah.

Peraturan Daerah Kota Gorontalo Nomor 9 Tahun 2011 tentang Pajak Bumi dan Bangunan Perdesaan dan Perkotaan.

Wardani, R., \& Fadhlia, W. (2017). Analisis efektivitas penerimaan Pajak Bumi Dan Bangunan Perdesaan dan Perkotaan dan kontribusinya terhadap Pendapatan Asli Daerah di Kabupaten Aceh Besar. JIMEKA: Jurnal Ilmiah Mahasiswa Ekonomi, 2(3) 10-17. http://jim.unsyiah.ac.id/EKA/article/view/4039

Wibisono, T., \& Mulyani, Y. S. (2019). Efektivitas pajak bumi bangunan perdesaan dan perkotaan terhadap Pendapatan Asli Daerah (PAD) di Kabupaten Tasikmalaya. Ecodomica: Jurnal Ekonomi, Manajemen \& Bisnis, 3(2) 133-140. https://doi.org/10.31311/jeco.v3i2.5841 